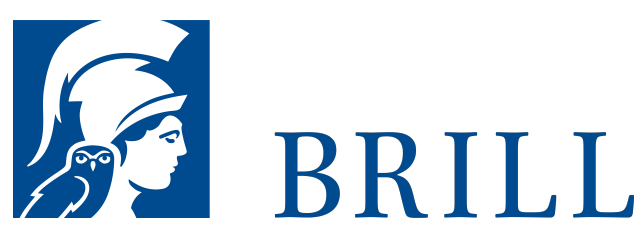

\title{
Politische Religion und Katholizismus
}

Geltungsgeschichten im faschistischen Romanità-Kult

Author: Claudia Müller

Roma caput mundi - Ursprung des Römischen Reiches, Zentrum der römischen Weltkirche, Hauptstadt des Faschismus. In Rom materialisiert sich das von Konsens und Konkurrenz gleichermaßen geprägte Verhältnis von politischen und religiösen Weltdeutungen.

Die Spuren imperialer Hegemonie und kriegerischer Macht haben sich in Rom ebenso eingeschrieben wie der universale Geltungsanspruch religiöser Ordnung. Auf dieser Basis rechtfertigte der faschistische Romanità-Kult der 193oer Jahre eine religiös-politische Heilsvision, die ein doch nur scheinbar einvernehmliches Miteinander des Faschismus mit dem Katholizismus beschwor. Am Beispiel der Mostra Augustea della Romanità untersucht die Autorin die religiösen Prägungen des Faschismus und die faschistischen Deutungen des Katholizismus. Mit einem soziologischen Instrumentarium plädiert sie für eine differenzierte Analyse von innerweltlichen Sakralisierungsmechanismen in Bezug auf Religionen und geht dabei weit über die diplomatischen Beziehungen zwischen Kirche und Staat hinaus.

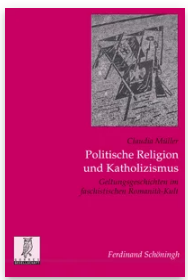

Pages: 291

Seiten, $4 \mathrm{~s} / \mathrm{w}$

Abb.

Language:

German

Subjects:

General,

Theology and

World

Christianity

Publisher: Brill |

Schöningh

Series:

Politik- und

Kommunikationswissenschaftliche Veröffentlichungen der GörresGesellschaft, Volume: 35

E-Book (PDF)

Released online: O2 Sep 2019

ISBN: $978-3^{-}$

657-78682-4

List price

Paperback

Publication date:

og Jun 2017

ISBN: 978-3-

506-78682-1

List price 
Biographical Note

Claudia Müller ist Referentin für Internationales im Bereich Geistes- und Sozialwissenschaften der TU Dresden.

For more information see brill.com

Order information: Order online at brill.com +44330 3330049 | customerservices@brill.com Submission information: brill.com/authors

Titles published by Brill | Fink, Brill | mentis or Brill | Schöningh: +49(o)715413279216 | brill@brocom.de 